\title{
2
}

\section{A Relationship Dominated by Employment Relations}

\section{Introduction}

An identifiable relationship between employment relations and social policy began in earnest in Australia and New Zealand before anywhere else, during the quarter-century before World War I. The relationship was not one with equal partners, as the two arms of social protection had different starting points. In his account of the wage-earners' welfare state, Castles (1985) makes that clear. His narrative misses key aspects of protection, however, which were to prove important both within the period and as each national regime developed into the future. The objective of this chapter is to account for the employment relations and social policy dimensions of social protection in the Australian and New Zealand settings with reference to the period from the 1890s until the Great War.

The importance of this chapter to the book as a whole is underlined by the birth of formal social protection during the period in question. Given this, the similarities and differences between Australia and New Zealand which developed in this era indicate the importance of the institutional inertia which characterises social protection through time. Employment relations were the predominant protective dimension in both countries. 
There was one main programme in each country that can be understood to be absolutely at the core to what became the welfare state, and that was the public pension, but there was in actuality no welfare state as such. In this way, the two regimes were similar, as the existing literature finds that they were. However, several major differences were manifested. The historical and comparative significance of these differences has been largely missed by all of the major strands of the comparative literature.

The differences stemmed mainly from two key factors relating to the interplay between politics, policy and institutions. Some of the institutions lay within and some outside of the social protection realm, strictly speaking. First, Australian social protection was mainly influenced by 'labourism', in the sense that labour movement strategy was the major driving force behind the institutions developed. By contrast, in New Zealand the government adopted its regime while taking greater notice of the interests of farmers. New Zealand had no political party which grew from the trade union movement. In addition, from its inception the Australian arbitration system was embedded within the Constitution and its function was constitutionally defined, whereas its New Zealand counterpart was established by government, with few if any constitutional guidelines as to its function. The New Zealand system was therefore set to be significantly more vulnerable to challenge by both trade unions and employers. The role and scope of factory legislation during the period were also a source of difference between the two regimes, mainly in that its New Zealand variant was nationally applicable, whereas in Australia its role at the national level was effectively quashed by the federal Constitution, severely limiting the hand of the national government in the direct regulation of working conditions.

Finally, the more explicit relation of arbitrated minimum wage standards to family needs in Australia, coupled with the stronger link drawn in that country between minimum wage determination and tariff protection, made arbitration a more historically entrenched component of social protection. This, when combined with constitutional limitations on national government involvement in state welfare in Australia, set in train a social security system which was less extensive than its New Zealand counterpart was. 
The first section of the chapter discusses the social, economic and industrial backdrop within which policy was formulated in both Australia and New Zealand. In doing so it provides the historical backdrop of the remainder of the comparative discussion. The second section covers Australia specifically, and the third discusses New Zealand. Each of the Australian and New Zealand sections outlines the social protection regime as expressed in minimum labour standards, respectively through factory legislation, industrial arbitration mechanisms and their policy accommodations, and state welfare programmes. Finally, the fourth section provides a comparative analysis of the two social protection regimes, pointing to the main similarities but also the major differences in both the substance of policy and the institutional and political backdrop within which policy was formed.

\section{The Trans-Tasman Context}

During the late nineteenth and early twentieth centuries, many of the kinds of minimum standards advocated by British and European theorists and social reformers were developed in Australia and New Zealand (Deakin and Green 2009; Macarthy 1969; Palmer 1931). The two countries were separated geographically by the Tasman Sea, on the other side of the world from Europe. Australia and New Zealand began their nonIndigenous histories as British colonial settlements, but at different stages. Australia was settled in 1788, becoming a federation of States in 1901. New Zealand was settled in 1840 , though it became a unitary state in 1876. The difference in the structure of the state would prove important, as will be seen later, but in both countries conditions for implementing national minima were more favourable than they were in Britain. Social protection was hard-fought, and reforms, many of them world-leading at the time, were won in the context of major social and economic upheaval. 


\section{From a 'Paradise' for Workers to Economic Depression}

From a comparative perspective, between 1860 and 1890 Australia was economically highly productive. Indeed, in 1870, it boasted a GDP per capita which was almost 75 percent greater than that of the United States, making it the most affluent country in the world (Caves and Krause 1984: 5). This prompted the comment that Australia was 'born rich' (Schedvin 1987: 21). British foreign investment in the period was diverted from other countries to Australia, feeding into massive public and private investment projects. The private programmes expanded the pastoral and extractive industries - including gold, silver, coal and base metals - while public investment focused upon the building of transport facilities, and, to a lesser degree, on urban social amenities such as water and sewerage. Macarthy (1967a: 45) argued that the willingness of Australian governments to become involved in economic and social affairs was in turn fed by pressure from pastoralists and business interests, which benefited from the state amenities to service their own enterprises. Industrial infrastructure thus grew relatively rapidly. In the Australian Colonies of New South Wales and Victoria, the government was the largest employer (Markey 1982).

With the exception of the pastoral sector, industry was highly labourintensive, and there were considerable labour shortages. These shortages in turn furnished relatively high wage rates for Australian workers, and low wage differentials between skilled and unskilled workers (Butlin 1964), given the particularly labour-intensive nature of many industries. Australia was seen as a 'working-man's paradise' (Castles 1988: 111-118). This optimistic view of Australian working life during the period, however, has been questioned by authors such as Patmore (1991) and Lee and Fahey (1986), who argue that such assessments are based upon aggregate statistics and employers' comments on labour scarcity, and thus do not reflect actual earnings. Further, Patmore (1991: 47-48) argues that earnings were somewhat irregular, largely because work was seasonal, temporary and casual. And in larger city settings, such as those of Sydney and Melbourne, slums developed. Regardless, it is generally agreed that the conditions of Australian workers were favourable on a 
comparative basis. Patmore (1991: 67) does acknowledge, for instance, that wage differentials in Australia were lower than they were in Britain, and that the relative position of Australian low-paid workers was comparatively favourable.

Between 1860 and 1890, New Zealand sat alongside Australia, the two being regarded as the richest in the world (Castles 1985: 95; Davidson 1989). During the 1860 s and 1870 s pastoralism was New Zealand's most lucrative economic pursuit. As a sign of the growth of the sector, between 1861 and 1870, the number of sheep in in the country increased 350 percent (Gardner 1981). In the 1860s the two staples were gold and wool, but by the mid-1870s wool had become the only staple, gold reserves having been depleted. By 1869 New Zealand had plunged into depression. Its people were compelled to look to the state as 'the only agency with the power to lift the Colony out if its stagnation', and 'to Britain as a generator of Colonial development', spawning an economic relationship which was to strengthen considerably from 1870 (Hawke 1985).

In consummating ties with New Zealand, Britain sent Julius Vogel, Colonial Treasurer from 1869, to take firm steps to rejuvenate the economy, principally through extended public works. His approach was characterised by a 'unified framework of national development', requiring the overriding of sectional interests (Woods 1963: 19). The finance for the development was raised in England, and immigrant labour was brought in to occupy the land after the jobs were created. The relatively harsh conditions faced by English agricultural workers meant that this was a group which was easy to convince to emigrate to New Zealand. From 1871 to 1880 , in excess of 100,000 immigrants arrived in the Colony, 50 percent being English, 16 percent Scottish, and the remainder German and Scandinavian (Sutch 1966: 54-57).

Vogel left office in 1876, by 1877 world prices had begun to fall, the government began to limit its borrowing and spending, and New Zealand entered a period of industrial depression which lasted until 1890 (Sutch 1966: 58-81; Gardner 1981: 75-83). During these years, New Zealand became urbanised, due more to an increase in the populations of the cities than to a movement of people from rural areas to urban areas. 
Provincialism was on the way out, and New Zealand's provinces were abolished in 1876 .

A decade later, Australia also fell into depression, forcing bank closures, company failures, wage cuts and underemployment (de Garis 1974: 217-225). Though there is little reliable data available, one historian estimates that, at its height in 1893, the depression delivered an unemployment rate of 28.3 percent (Macarthy 1967a). There was a return to prosperity in 1900-1901, but this was brief, and drought prolonged the economic stagnation until 1906.

\section{‘New Unionism”}

Associated with the movement towards depression from the late 1880s in Australia was a fundamental restructuring of industry, which brought with it a change in the conduct of relations between employers and workers. The industrialisation which was occurring placed new demands on workers, who began to see the greater importance of being organised into unions. The concept of 'new unionism' has been used to describe this seemingly different basis of union organisation. New unionism was generally characterised by 'the extension of unionism beyond urban tradesmen to workers in industries such as mining, railways, road transport, shipping, pastoralism, and construction during the 1870s and 1880s' (Patmore 1991). This additional sector of the union movement reflected the unionisation of unskilled and semi-skilled workers, thus taking unionism beyond the craft basis which the movement had developed from Britain, though unions remained predominantly craft-based organisations.

Controversy exists, however, among labour historians as to how truly 'new' the new unions were. Turner (1976), for instance, claims that new unions characteristically organised workers who were not organised into craft (or occupational) unions, the traditional basis of Australian trade unionism. They had an open membership, did not seek benefits such as unemployment pay, were usually intercolonial rather than locally based and were more militant and politically radical than craft unions. On the same side of the debate, Markey (1982: 106) argued that new unionism 
was associated with the 'proletarianisation' of the Australian working class. On the other hand, authors such as Patmore (1991: 67-68) and Docherty (1973: 61) argued that there is no easy distinction between the old and new unions since there is no clear historical dividing line between them. Regardless, it is credible to assume that, though the point in time at which new unionism took hold is uncertain, and though union membership suffered a crisis in the 1890s, there was a change in the type of unions within which workers were organised.

'New unionism' is also a concept used to describe New Zealand in the same era. There, union membership rose steadily from the 1870 s, and more dramatically after 1899-90 (Deeks et al. 1978; Roth 1973; Olssen and Richardson 1986). A high proportion of the new unions were in semi-skilled and unskilled occupations, as well as some among women workers. In 1889-90, a myriad of new unions were formed, the number rising in Auckland from seven in early 1889 to thirty-four in late 1890 . Holt (1986: 19) argues that new unionism in Britain and Australia had a 'stimulating effect' on unionism in New Zealand. Other explanations exist, however, including one which states that the economic upswing of the period enhanced labour's bargaining power, encouraging workers to join unions (Sinclair 1961).

\section{Industrial Unrest}

The shift in union structures in the two countries was also important as an indicator of a shift in industry. Together, these two factors lay at the heart of a turning point in employment relations which was marked by an increase in industrial action. In Australia, a series of major strikes occurred, beginning with the maritime strike of 1890 . This was as close to a general strike as Australia had yet come to in its history. From April to July 1890, the maritime unions were putting pressure on the owners of ships engaged in coastal trade for improvements in wages and other conditions. The employers did make concessions to the wharf labourers and the seamen. However, the Marine Officers were informed that a deal would be struck only if they cancelled their recent affiliation with the 
Melbourne Trades Hall Council. On 16 August, the workers struck, having rejected the ultimatum.

Soon the wharf labourers, stewards, seamen and cooks struck in sympathy, but also partially because of grievances of their own. The maritime strike highlighted the clash of two conflicting desires: of the shipping employers to hire whomever they deemed suitable, and of the trade unions to refuse to work alongside non-union labour. This conflict was at the heart of the other disputes of the period. For example, a strike by the Queensland shearers and another in 1894 were in response to the use of non-union labour. The New South Wales Coalminers also struck another three times between 1892 and 1896, without success. The employers had asserted their prerogative to hire non-union labour with the help of the state (de Garis 1974). As discussed further on, this form of state assistance to employers, which effectively represented a tacit partnership between the two parties, partially explains the establishment of arbitration.

The great conflicts which occurred in New Zealand from the late 1880s to the 1890s mirror, and to a large extent are intimately connected with, those in Australia. When the first wave of strikes occurred in New Zealand, between 1872 and 1875, prices were rising, the economy was booming, and there was a shortage of labour. All of these factors worked in favour of striking workers in their quest to increase wage rates (Woods 1963). However, in the depression after this period, the strike weapon became virtually ineffective as the unemployed workers, who were often destitute, were ready to take up positions lost by strikers. Also, a high proportion of workers were not unionised, making it doubly disadvantageous to strike. During this stage, working conditions deteriorated. Wages fell, hours of work lengthened, and the labour of children replaced that of adults. As will be seen, it was this climate which prompted the establishment of a body of factory legislation providing minimum labour standards.

By 1885 , however, unionism had both gained in strength and to some extent in unity. In that year, the Trades and Labour Congress met in Dunedin, and again the following year in Auckland (Sinclair 1961: 182). In 1885 , a union of miners struck on the basis of employer refusal to employ union labour. The union was defeated because it was without 
funds and lacked outside support, and it was temporarily disestablished. A series of strikes followed in the late 1880s in response to the lowering of conditions, and out of efforts for employer recognition of trade union rights. Such strikes were often sporadic, local and poorly organised. However, in 1890, the maritime strike, which began in Australia over the dismissal of a union delegate on a steamship, spread to New Zealand (Richardson 1981: 197-198), affecting mainly the waterfront and the coal mines.

It has been estimated that 50,000 Australian and 10,000 New Zealand workers were directly involved in the maritime strike, and 200,000 women and children were financially dependent upon the strikers (Deeks et al. 1994: 43). Its potential impact in terms of social protection upon workers who were dismissed, and their families, was thus significant. As it turned out, the strike lasted for fifty-six days and was conducted when farmers and farm workers were available to act as strike-breakers. In addition, public opinion was against the strikers, largely because the issue was thought to be an Australian one, and thus had its basis externally to New Zealand. The unions were defeated, employers could institute the condition that workers be non-unionised and as a result the number of unionists declined.

\section{Australia}

Long before the 1890 s, the state had taken an interventionist stance on the employment relationship. However, many of the early legislative interventions were antithetical to social protection, being merely instruments to control labour, thus strengthening the hand of the employer. This applied to Australia as it did to Britain. More than seventy statutes which treated the employment relationship as one of 'masters and servants' were passed between 1828 and 1900 (Quinlan 1989; Patmore 1991; Merritt 1980, 1982). These were designed to place restrictions on labour mobility, worker abscondence and misconduct. Special legislation regulating the merchant seamen and whaling workers was also implemented, mainly because maritime transport was important to remote colonies dependent on trade, and thus the legal control of workers in the 
industry was seen as important. In this context, social protection was all the more necessary.

\section{Minimum Labour Standards Through Factory Legislation}

Faced with state hostility in the form of masters and servants legislation, many unions sought the advancement of their rights through friendly society laws (Ebbels 1965). As the colonies developed further, however, the legal system gradually became less repressive and more protective of workers and trade unions. For instance, all colonies except Western Australia adopted the (British) Trade Union Act, 1871, which protected the funds of unions and deemed that their activities were not in restraint of trade (Gollan 1960). In shaking off the free-market ideological assumption that trade unions necessarily impede employers' decision-making capacities, and that they place restraints on trade and market forces generally, this piece of legislation represented a significant development in the shift from worker-hostile to worker-friendly legislation. Factory legislation furthered this process again. The story of the growth of these laws is one of the incremental extensions of protection to workers over time. The beginnings were in the late nineteenth century.

In addition to trade unionism, factory legislation based on the British model was the predominant means of legal protection for workers before the introduction of compulsory arbitration. In Britain, factory laws were the main means used in the fight against 'sweated' labour in Britain. More significantly, however, it was the primary vehicle for creating what the Webbs (Webb and Webb 1897, 1911) called the 'common rule', which was their conceptual basis for national minimum. Factory legislation used statutory means to implement irreducible minimum standards regarding conditions of work, though, as will be seen, their coverage was typically far from uniform within and across industries. The 'common' aspect of the 'rule' that expressed the minimum standard often did not apply.

In Australia, the first of such legislation was established in the colony (from 1900 the State) of Victoria as the Factories Act, 1873. Primarily a 
response to disapproval within the press of the poor working conditions of women in the Ballarat clothing trade, this Act defined a factory as employing ten or more workers, and prevented women from working more than eight hours. Employers, however, were able to evade the Act by reducing the size of their workforces to nine, opening smaller workshops and using outworkers. The Act also suffered the limitation that factory inspection, designed to police implementation, was highly ineffective. A new Act in 1885 made the provisions more effective by reducing the minimum number of employees to five, and then by an amendment in 1893 to four. The new Act also improved inspection, and included provisions for cleanliness, air, space and sanitation within the workplace. It also regulated the opening hours of shops, dictating that seven o'clock should be the latest evening closing time during weekdays, and ten o'clock on Saturday nights, though shops selling certain types of food and perishable products were exempt (Coghlan 1918/1969: 2089). However, the Act only applied to cities, towns or boroughs. Employers could thus shift the location of their operations and offer outwork. The 1873 Act provided health and safety regulations, the protection of child and female labour, and inspection (Markey 1988).

From 1862, the colony of New South Wales implemented statutes regulating coal mines. In 1876, legislation prohibited the employment of females of all ages, and boys under thirteen years of age, and restricted the working hours of male and female youths between thirteen and eighteen years of age (Markey 1988). In another important piece of legislation, in 1890, the New South Wales legislature passed a Census and Industrial Returns Act, by which the government statistician was empowered to report on the condition of factory and other employment in the colony. Based upon investigations of factories and workshops in all of the major population centres of the colony, during 1891 and 1892, the statistician reported that lack of sanitation and the significant incidence of home work, often underpaid, were the key problems. It was also found that apprentices were often not paid at all. In 1896, albeit after a significant delay, a Factories and Workshops Act was passed, modelled on the Victorian Act of 1885 (Coghlan 1918/1969). The New South Wales legislation was limited, however, mainly by three factors: first, its minimum provisions for safety, ventilation and the limitation of the hours of women and 
children were restricted to the large urban centre, Sydney; second, inspection was largely ineffective; and third, government employees were beyond the Act's reach.

The piece of legislation with the most successfully applied provisions and which came closest to the implementation of the national minimum-though it applied only in one colony-was the 1896 Victorian Factories and Shops Act. This extended the coverage of the 1893 amendments to the 1885 Act in several ways. First, it broadened the definition of a factory to include 'every place in which furniture was manufactured, to every place in which Chinese were engaged in laundry work, and to all industries where four persons were employed, excepting those carried on by charitable institutions' (Coghlan 1918/1969: 2093). Greater powers were given to factory inspectors, including the capacity to prosecute any employer who provided an insanitary factory or workshop. Chief inspectors were given the authority to condemn any workplace considered unsafe or dilapidated. The provisions covering the employment of children and young persons were strengthened, and hours of work regulations were made more stringent. The Act prohibited the employment of any child under thirteen years of age, and no female person of any age, and no boy under sixteen years, could be compelled to work more than a ten-hour day, or after nine o'clock in the evening. In furniture factories and laundries where a Chinese person was employed, work was not to begin before 7.30 am and could not continue after $5.30 \mathrm{pm}$ on weekdays, or $2 \mathrm{pm}$ on Saturdays. All Sunday work was made illegal (Coghlan 1918/1969).

A few years after Federation, which transformed the colonies into States of the Commonwealth of Australia, innovations in national minimum labour standards came from arbitration mechanisms and their policy accommodations, and not from factory legislation.

\section{Wages Boards and Compulsory Arbitration}

The 1896 Victorian Act was significant not merely for its improvement on previous Australian legislation in terms of coverage, and hence its protective capacity, but also because it set down guidelines for the 
establishment of wages boards in specific trades or industries in that colony. The wages board and arbitration systems of the colonies were highly similar in intent, each with the state as primary player but allowing unions a place to advocate for higher minimum labour standards.

The term arbitration has been used as shorthand for both the procedures of conciliation and arbitration on the one hand, which applied in all but two of the Australian colonies, and wages boards on the other, which prevailed in Victoria and Tasmania (Macintyre and Mitchell 1989). With some variations, depending on the state (or the colony before 1901), compulsory arbitration involved state tribunals in the exercise of a legal responsibility to settle industrial disputes and give their decisions the force of law. Within arbitration guidelines there were usually provisions for the registration, and therefore recognition, of unions, and either trade union or employer ordinarily could take the other party to the tribunal for a dispute to be arbitrated.

The wages boards systems used tribunals of an equal number of employer and employee representatives within a particular industry, and a chairperson who, at an industry level, periodically determined minimum wages and other conditions. The wages boards did not require formal disputes to call the procedure of determining working conditions into force, whereas arbitration generally did. Boards also did not require the registration of bodies representing workers and employers; neither did they place limitations upon direct action between the parties. Both of those characteristics did not apply to arbitration. However, the wages boards and arbitration systems shared the element of compulsion. Both could compulsorily determine wages and other working conditions, and force all parties in an industry or occupation to comply with the determination (Patmore 1991). Though arbitration also existed in New Zealand, as discussed later in this chapter, it was this feature which was missing in similar systems internationally, notably in Britain, Europe and North America (Mitchell 1989).

The establishment of wages boards and arbitral tribunals from the 1890s was part of the already extensive role played by the state since the middle part of the nineteenth century in the regulation of the economy and employment relations (Schedvin 1987; Brugger and Jaensch 1985: 3-23; Patmore 1991; Quinlan 1989; Macarthy 1967b; Markey 1982). 
But both trade unions and employers played important roles in the establishment of arbitration. Some authors have argued that the unions, weakened by economic depression and defeats in the strikes of the 1890s, were forced to compromise their traditional opposition to state intervention in the employment relationship and allow the state to impose binding resolutions to industrial disputes and determine wage levels and other working conditions (Gollan 1960; Macarthy 1970; Rickard 1976). Thus the union movement had to have faith that the state had switched the emphasis of legislation away from repressive regulations established under masters and servants law, as discussed earlier. Another union consideration was that factory legislation, which was protective, still had limitations.

Fitzpatrick (1949: 228-229) argues that employers initiated arbitration in order to dilute the militancy of unions. In this view, the unions were generally not opposed to arbitration because in the name of expediency they saw it as a feasible alternative to direct bargaining. On the other hand, others suggested that, far from forcing arbitration upon trade unions, employers generally fought against it, even though they came to see it as beneficial after 1905, by which time the economic downturn had been reversed (Patmore 1991; Macintyre 1989; Plowman 1989). Generally speaking, however, arbitration was predominantly a union goal as it was seen as an avenue for the maintenance and improvement of worker protections.

Arbitration models adopted in Australia and New Zealand were exceptional in having the element of compulsion, but they did have international antecedents (Mitchell 1989). In the United Kingdom, commercial arbitration dates back to Saxon times, dealing only with existing commercial contracts. The legislative regulation of wages and other conditions had its origins in the 1349 Ordinance of Labourers. This involved magistrates and justices of the peace in the settlement of disputes and the establishment of some working conditions in particular industries. The industrial revolution and the ascendancy of the doctrine of laissez-faire, however, curtailed the usage of third-party intervention, and by 1800 , when the Combination Act was passed, a trend of state abstention had begun, prevailing for most of the rest of the nineteenth century. Within this environment, non-compulsory commercial arbitration became the dominant form. Also in 1800, a Cotton Arbitration Act was passed, 
allowing employers and workers to seek arbitration unilaterally on disputes over existing contracts and new grievances. However, the Act's major pitfall was that it only recognised individual and not collective disputes. Both of these pieces of legislation were repealed in 1824 . Between 1860 and 1890, voluntary industrial conciliation and arbitration boards were set up by employers and unions in particular industries, notably building and coal mining, though these were effectively forums facilitating collective bargaining.

Though some well-known European examples of arbitration also preceded the Australasian arbitration systems (Mitchell 1989; Patmore 1991), North American and particularly Canadian arbitration experiments were of most direct relevance. In the 1880s and 1890s several of the US states established legislative schemes whereby conciliation and arbitration mechanisms would play a role in determining working conditions, though these were for the most part based on the British voluntary model. In Canada, the most significant example lay in the Nova Scotia government's enactment of the Mines Arbitration Act of 1888. Mitchell (1989: 82) argues that 'this seldom-noted statute was the first in any English-speaking country to completely cast off the notions of master and servant $\ldots$ and to provide for a system of compulsory arbitration over disputes of interest between collectivities of workers and their employers'. However, it had its limits. First, it was limited to the coal-mining industry. Second, it only applied to disputes regarding wages, and not to other employment conditions. Moreover, there was no provision for the registration of trade unions in the arbitration process. Finally, it was only ever used twice.

The 'classical form' of Australasian compulsory arbitration (Mitchell 1989: 89) derived from key pieces of arbitration legislation in Western Australia (1900 and 1902), New South Wales (1901), the Commonwealth (1904), South Australia (1912 and 1915) and Queensland (1912 and 1916). These laws all shared certain key defining characteristics. First, tribunals, comprising courts, boards or a combination of the two, were a feature of each of them. Second, they each had a system of registering and regulating associations of employers and employees. Finally, they each had an administrative wing. The feature which distinguished them from comparable overseas experiments, however, was compulsion. 
Kahn-Freund (1972: 93-94) attributes four possible meanings to the term 'compulsory' when applied to the resolution of industrial disputes. He argues that a system of dispute resolution is compulsory in the sense that the parties must use the procedure, whether or not they are allowed to reject the outcome or resolution; the procedure might be forced upon both parties to the dispute, such that either party or neither party need provide consent for the procedure to come into effect; the award is binding upon the parties, whether or not they accept it; or finally, while the procedure is in use, direct action such as strike or lockout is illegal. Mitchell (1989: 90) saw the last three categories as being generally applicable to the Australasian model, though the first was subject to legal interpretation.

\section{'New Protection', Industry Protection and the White Australia Policy}

While the federal or Commonwealth arbitration jurisdiction in Australia became the most significant, the arbitration system is best understood as an element in the broader policy of 'New Protection'. This explicitly linked the provision by employers of fair wages with industry protection, mainly in the form of tariffs. The 'essentials' of New Protection had been developed in Victoria, where manufacturing was most advanced. In Victoria tariff protection was introduced from the 1880 s, encouraged by a protectionist alliance between manufacturers and trade unions. Industry protection provided manufacturers more certainty with regard to profitability, such that it proved economically expedient for them to be socially 'reputable', mainly by ensuring workers had employment with fair wages and other conditions. The alliance had also formed the rationale for factory legislation to combat sweating (Markey 1982). As discussed further in this chapter but also in the remainder of the book, the state basis of arbitration in Australia, as against its unitary national basis in New Zealand, was an important difference for the purpose of comparative analysis.

In the early Australian Commonwealth, the linkage between industry protection and social protection for workers was made more explicit than 
had been the case in Victoria. A contest between free traders and industry protectionists was resolved in favour of the latter in the form of New Protection, which became the basis for a 'national social policy' from the very early post-federation years (Markey 1982: 110; see also: Macintyre 1985; Macarthy 1970). A tariff was developed in 1902. Introduced a few years later, several Acts of Parliament applied the principle that tariff protection was conditional upon the employer providing fair working conditions. The most noteworthy of these were the Customs Tariff Act of 1906, which ensured the reputable employer double protection, with the imposition of import duties equal to twice the excise duty; and the Excise Tariff Act of 1906, which allowed the employer an exemption from excise duties if they could show to the satisfaction of the Arbitration Court that the wages they paid were 'fair and reasonable'.

However, social protection by means of the policy of New Protection was pursued more broadly than just within the arbitration system, because decent wages and other working conditions were also made possible by a highly selective immigration policy, and the protection of those considered worthy of social security in their old age by means of pensions. Leaving pensions aside for now, the selectiveness of immigrationsuch that cheaper non-white labour was excluded-was also meant to protect conditions for Australian workers. The Immigration Restriction Act of 1901, the main legislative basis for the 'White Australia Policy', was designed to exclude 'undesirable' immigrants, establishing the principle that a prospective immigrant could be forced to undergo a dictation test in any European language. The Pacific Island Labourers Bill of 1901 complemented this by preventing Kanaka (Pacific Islander) labour in Queensland's sugar industry. There was little opposition to the White Australia policy, the policy being the first substantial body of legislation enacted after the Federation (Markey 1982).

The White Australia policy was motivated by two interrelated factors, dating back at least to the 1870s: first, the protection of wage levels through the exclusion of cheap labour from 'undesirable' lands, mainly Asia; and second, by an express (racist) popular dislike of people of nonwhite backgrounds. It was popularly conceived that the challenge of safeguarding the conditions of Australian workers should be met by preventing undercutting by cheaper overseas competition, in much the 
same manner as tariffs protected Australian industry from overseas competition. Racism, however, manifested itself in the desire to keep the race 'pure', lest 'our sisters or our brothers should be married into any of these races to which we object' (J.C. Watson, quoted in Markey 1982: 118).

\section{The 'Harvester' Judgement and Minimum Wages}

The Harvester wage decision of Justice H.B. Higgins, the second and most historically pivotal President of the Arbitration Court, was also used to prevent the wages of Australian workers from being undercut. The decision was also discriminatory, though on the basis of gender. In the famous case, the Sunshine Harvester Company applied to the Arbitration Court for an exemption of its excise duties under the Excise Tariff Act. In considering the application, Justice Higgins decided that this would be a test case for the establishment of a minimum wage based upon 'the normal needs of the average employee, regarded as a human being living in a civilized community', and not the profitability of the firm, though 'the profits of the industry may be taken into account' (Higgins 1920: 14, 17, 20). Based upon an assumption that 'women are not usually legally responsible for the maintenance of a family', and that men were, the minimum or 'living' wage afforded men a higher rate than women.

In deciding the Harvester case, Higgins argued that the purpose of his Court was not merely to 'cut back the rising incidence of industrial strife', but also 'to provide a minimum standard of living for all Australian male wage earners' (Macarthy 1969: 35). Higgins (1920: 14) argued that the Conciliation and Arbitration Act 'was designed for the benefit of employees, and that it was meant to secure for them something which they could not get by individual bargaining with their employers'. Following the Webbs' conception of a national minimum, the minimum wage was not a maximum or even an average wage, merely a wage floor. Higgins considered it important to allow for wage differentials according to 'skill and other exceptional qualifications necessary for the successful performance of the work'; for this purpose he introduced a 'secondary wage' (Higgins 1920). This was also consistent with the national minimum 
arrangements advocated by the Webbs (Webb, B. 1919; Webb and Webb 1897: 749-766).

Despite being first set down in 1907 , the minimum wage-or the 'basic wage' as it became known — was not received by most workers until the 1920s. There were two reasons for this: first, most workers were members of state and not federal unions; and second, the minimum wage could only be applied as new cases came before the court. However, the framework of the national minimum, channelled through the Arbitration Court, was established in 1907 . The most important unions were interstate, and many 'new unions' registered under the Conciliation and Arbitration Act. Under the Act, both employers and trade unions registered with the Court, and could unilaterally enforce a decision by the Court in resolution of a dispute. Awards were legally enforceable, though before awards were formulated by means of arbitration, conciliation was encouraged. The Act prohibited strikes and lockouts, and awards generally imposed a 'common rule'. In addition, as highlighted by Higgins (1920: 23) himself and historians such as Markey (1982: 114), most State arbitral tribunals began to follow the minimum wage concept set up by the Commonwealth Court.

\section{State Welfare}

Drawn during the two decades on either side of Federation, the Australian combination of wage protection and industry protection, alongside the White Australia policy, did not entirely complete the picture of the nation's social protection pattern. The final element added was that of welfare outside of the labour market. The state had begun its involvement in the provision of welfare services after the mid-nineteenth century, albeit in a highly limited and selective manner. Under this system, various categories of people were subject to poverty relief strategies. The state did, however, provide limited services for various categories of poverty-stricken people, including the destitute, the sick, the unemployed, the aged and children. These arrangements did not resemble a 'welfare state' because in no way did they represent any coherent strategic regime on the part of the state to accept the responsibility of taking its 
people - at least those who fell outside of the labour market-beyond the condition of bare subsistence. Such measures were mainly 'charitable', and only complemented charity from private sources (Dickey 1987; Kennedy 1985; Kewley 1973; Mendelsohn 1979). Yet, as argued in this book, the state welfare services offered during the period did shape a future social protection regime when considered in combination with minimum standards legislation, compulsory arbitration and the 'new protection' programmes.

As well as the kind of help associated with these services, all of the Australian colonies adopted workers' compensation systems, modelled on the British programme model. Based on the insurance principle, the employer made regular payments to cover their employees in the case of workers suffering a work-related injury or accident. As Castles (1985: 16-17) recognised, however, the workers' compensation schemes were not of great historical significance to social protection, mainly since the numbers covered by them were small. In addition, the payments made by employers came to be considered as merely adding to the costs of production, rather than constituting a major social protection measure. Yet, they did form part of the package of benefits that Richard Titmuss (1956/1976) later termed 'occupational welfare'. This was a part of the overall picture of welfare provided in society, though ordinarily it is not paid by the state, and it usually leads to greater rather than lower inequality.

The only significant policy measure in the welfare area outside of the employment realm, at least in terms of the influence it had on the subsequent development of the Australian social protection pattern, lay in the area of pensions legislation. The New South Wales government introduced an Old Age Pensions Act in 1900, offering a pension to men and women over 65 years of age who had been resident in the country for over 25 years. Compared with Justice Higgins's decision in the Harvester case, the level of this pension was not generous. Despite the legislators' claim that it was a reward for hard work, rather than representing mere charity, the pension upheld a distinction between the deserving and undeserving poor, and was thus highly selective.

The administration of the pension expressed a preference for applicants who could demonstrate poverty, what was deemed appropriate conduct, that applicants had been sober and 'respectable' for five years 
running, and that they were free of criminal conviction for twelve years (Carney and Hanks 1994: 30-32). Victorian legislation introduced in 1901, the Old-Age Pensions Act, was based upon the same principles, though its arrangements were more stringent. This was due mainly to Victoria's more influential 'traditions of charitable action', charity organisations generally preferring to offer voluntary relief to the deserving poor rather than poverty prevention by means of more universal state benefits (Dickey 1987: 90). Finally, the Commonwealth pension, under the Invalid and Old Age Pensions Act of 1908, was modelled on the New South Wales Act.

The question of 'need' on the part of pension applicants was all but irrelevant to the legislators in all of the Australian jurisdictions, including the Commonwealth. Welfare law scholars Carney and Hanks (1994: 32-33) characterise the pension legislation of the period as 'heavily infused with the values and philosophy of "social deserts":

Need, of itself, was seen as an entirely inadequate justification for attracting government support. Public moneys were to be expended only on citizens of long standing who, by their endeavours in years past, had laid the foundations for community well-being. Support was extended to the aged and to invalids on the basis that they had contributed to community prosperity, and were now unable to participate in productive activity, or that, through no fault of their own, they were denied that opportunity to participate.

\section{New Zealand}

Much of the context within which social protection developed in New Zealand over the latter part of the nineteenth century and the early 1900 s, and indeed many of the protective policy measures implemented, were highly similar to those prevailing in Australia. In order to avoid repetition in the areas of crossover, therefore, this section is considerably more concise than the previous one. A shorter discussion of New Zealand is justified also by the absence of states in that country, which produced uniform policies for the entire country. 


\section{Minimum Standards Through Factory Legislation}

The body of factory legislation which developed in New Zealand in the period was similar to its Australian counterpart. Though the strike weapon had failed after the 1890s_-just as it had in Australia_-laws had been and were being implemented which would improve the position of workers. The first of these were the factory laws. With the urbanisation of New Zealand's population, successive governments became more aware of the increasing importance of the urban industries, and labour legislation was one response. Early legislation was only mildly reformist, and largely reflected developments in other countries, mainly Britain and Australia. The Master and Apprentice Act of 1865 provided for the engagement of apprentices in government departments and charitable institutions, as well as regularising the conditions of apprenticeship. The Offences Against the Person Act of 1867 furthered the protection of apprentices. The 1871 Contractors Debts Act represented a preliminary wage protection measure, though more definite steps in this direction were taken in the introduction of the Employment of Females Act of 1873 (Woods 1963: 19).

This Act represents the first major attempt to redress the problem of labour exploitation, though its lack of novelty from a comparative perspective lay in the fact that it was largely a copy of a similar Act passed in Victoria (Deeks et al. 1994: 39-40). Leaving aside its effectiveness on a comparative basis, it also failed because, like much of the protective legislation enacted across the Tasman in the period, it lacked effective provision for inspection and its coverage was not nearly extensive enough to establish a 'common rule' in industry. Yet it represented a step in this direction. Only applying to women and girls, the Act simply provided for an eight-hour day, outlawed factory work between 2 pm on Saturday and 9 am on Monday, prohibited work earlier than 9 am or later than $6 \mathrm{pm}$, and allowed four holidays in the year: Christmas Day, New Year's Day, Good Friday and Easter Monday. It also made provision for sanitation and ventilation, and defined a workroom as any place of employment containing one or more persons working on articles for trade or sale. The Act was amended the following year and again in 1875 , such that it 
became illegal to employ children of either gender under ten years of age in factories (Woods 1963). Despite its limited scope and its low capacity to impinge upon the exercise of employer prerogatives, some employers protested against it, and a petition was signed by some Canterbury employers saying it was 'altogether unnecessary, harassing, and calculated to injure trade and industry' (Sutch 1966: 74-75).

Small advancements in factory legislation were made in the 1880s. For example, the Employers' Liability Act of 1882 enabled workers or their dependants to be compensated by the employer for the death or injury of the worker resulting from the negligence of another employee or the employer. In response to press reports of the increasingly widespread incidence of sweating in industry, however, the government set up a nineperson Royal Commission to inquire into the existence or otherwise of a sweating system within which workers were exploited. This, coupled with the growing influence of the trade union movement upon the advent of 'new unionism', stimulated the extension of the factory law code (Woods 1963: 23-25). One of the most significant pieces of legislation it encouraged was the Truck Act of 1891, which prohibited the payment of wages in any form other than money. The Factories Acts of 1891 and 1894 controlled hours of work and introduced health and safety measures, all policed by factory inspectors. The Employment of Boys or Girls Without Payment Prevention Act of 1899 introduced a universally applicable, albeit extremely modest, minimum wage for workers under twenty years of age (Brosnan and Rea 1991).

\section{Compulsory Arbitration and Its Policy Accommodations}

By the 1900s, factory legislation had acted, although by no means completely, to provide the New Zealand worker with various minimum standards: protection against accident; a means of payment of wages; sanitation, ventilation and safety at work; control of hours of work; and some limited protection in the form of minimum wage rates. Further action in the field of minimum standards legislation would have been one means of providing a complete body of law enshrining the principle of 
the national minimum. Greater comprehensiveness was not undertaken through further minimum standards legislation directly, however, but through the Industrial Conciliation and Arbitration Act of 1894. Like Australia, though well before it, New Zealand adopted a compulsory arbitration system.

For Woods (1963), author of one of the very few histories of New Zealand's arbitration system, the Arbitration Act, as it became known, had its roots in two movements: one advocating the regulation and protection of working conditions, especially in light of the abuses seen under the sweating system; and the other supporting the regulation of the conduct of industrial relations, inspired mainly by the industrial conflict seen in the early 1890 s as discussed earlier. Both of these movements were supported by the labour movement, and both were by and large denounced by employers, who had a majority representation in the Legislative Council, New Zealand's second parliamentary chamber. The Council operated in a different manner to Australia's Upper House, the Senate, and only between 1853 and 1950 .

The New Zealand Arbitration Bill was only passed on the third occasion, first being proposed in 1891, being accepted in 1894 and coming into force the year after. Devised by William Pember Reeves, Minister of Education and Justice and then Minister of Labour, the Arbitration Act was designed to 'encourage the formation of industrial unions and associations and to facilitate the settlement of industrial disputes by conciliation and arbitration' (Deeks et al. 1994: 45). The Act established Conciliation Boards, consisting of two to three people elected by the employer and the same number by the trade union. Together, the employer and the union would elect a chairperson. Either party could unilaterally take a dispute to the board, which could of its own accord investigate a dispute. If either employer or workers were dissatisfied with the decision of a conciliation board, the matter could unilaterally be taken to the Arbitration Court, which had the power to make legally binding awards in a manner much the same as its Australian counterpart. Both employers and unions could register under the Act, though the former were slower to do so (Deeks et al. 1994: 54).

Though there was a link between compulsory arbitration and industry protection as a basis for trade policy, the link was less strongly 
institutionalised in New Zealand than it was in Australia. Australia enshrined the policy of New Protection, establishing the principle that industrial protection would only be provided to 'reputable' employers, who paid minimum wages deemed decent. In New Zealand, the link between wages and industry protection was not as entrenched, and neither was it quite as significant as its Australian counterpart. Chapter 3 elaborates on this point. As Mabbett (1995) argues, in long-term historical perspective, New Zealand employers, like their Australian counterparts, were spurred to pay decent minimum wages by being provided with protection, the latter coming in 1888 in the form of a general tariff.

The immigration policy of excluding Asiatics, also motivated by the same justifications as in Australia, was institutionalised in New Zealand. Writing during the period dealt with in this chapter, Le Rossignol and Stewart (1910: 281) put the New Zealand case used for selective immigration clearly:

That the depressing effect of immigration upon wages is no mere theoretical abstraction[] is clearly seen in the attitude of the workers of New Zealand and Australia toward Chinese and other Asiatics. ... [In New Zealand, t]here is a poll-tax of $£ 100$ (\$500) on Chinese immigrants; and 'The Immigration Restriction Act, 1908'[] prohibits the landing of lunatics or idiots, persons suffering from a dangerous or loathsome contagious disease, certain convicted criminals, and any person other than that of British birth who fails to write out and sign, in any European language, a prescribed form of application.

Without the formal label, New Zealand pursued a social protection package highly similar to that of Australia, though without words like 'New Protection' in formal titles and without a racially 'White' basis for population policy.

\section{State Welfare}

As was the case across the Tasman in Australia, the state, complemented by voluntary or charitable institutions, entered the arena of welfare services from the mid- to late nineteenth century, predominantly to relieve 
obvious distress and dire poverty. The main groups targeted, for the most part those deemed among the 'deserving poor', included children, the aged, the sick, the able-bodied unemployed, the permanently infirm and disadvantaged (but married) mothers (Oliver 1977; Davidson 1989; Sutch 1969; 1966). Workers' compensation, which took the same basic form as the Australian system, was ushered in around the turn of the century with the Workers' Compensation Act of 1900. The introduction of an accident branch of the Government Insurance Department in the following year made it different from Australia (Sutch 1969: 117, 155; Castles 1985: 16-17).

The state welfare measure which provided the closest precedent to the system that developed subsequently, however, was the pensions legislation. New Zealand has the distinction that it introduced the world's first national pension scheme. But old-age pensions constituted the only government measure in the area of income maintenance, the Old Age Pensions Act coming into force in 1898 (Oliver 1977: 5, 11; Overbye 1997: 101-102). As with its Australian counterpart introduced eleven years later, however, the major feature of the New Zealand pension was its high degree of selectivity. It was targeted stringently at those considered the deserving poor. As a sign of this, by 1904 , only 35 percent of those who qualified for the pension received it.

\section{Comparative Analysis}

\section{The State of Knowledge}

The literature directly comparing Australia and New Zealand generally base their analysis on the recognition that the two nations bred regimes in the 1890s and 1900s which were essentially variants of the one type (Allan et al. 1998; Bray and Haworth 1993; Bray and Nielson 1996; Bray and Walsh 1993, 1995; Brosnan et al. 1992; Castles 1985, 1996; Castles and Pierson 1996; Castles and Shirley 1996; Deeming 2013; Wailes 1999; Sandlant 1989). For example, while also emphasising more recent differences since the 1980s, Bray and Haworth (1993: 2-4) argue: 
To most external observers, Australia and New Zealand are very similar, if not identical societies, proximate to each other and born as British colonies at broadly the same time. ... The two 'settler' societies subsequently grew in similar ways. ... The economic basis of both economies was also similar in that their early economies were dominated by primary industries strongly oriented to the markets of the colonial power. ... The common British heritage in Australia and New Zealand resulted in remarkable social and cultural similarities. Citizens of the two countries spoke the same language, read similar books, listened to similar music, played the same sports, fought in the same army units, shared the same respect for individualism, and suffered the same disillusionment with the colonial power as it rethought its international orientation in the 1960s and 1970s.... Political parties evolved in similar ways. In both, divisions grew between an originally rural political tradition, later urbanised into a manufacturing and agricultural capital alliance, and a primarily urban labour tradition found most explicitly in the Labour/Labor parties of both nations. ... Interestingly, the balance of power between the labour and conservative parties in both countries has followed a remarkably similar path.

In his pivotal contribution, Castles (1985; 1996; Castles and Pierson 1996; Castles and Shirley 1996) elaborates on how and why the Australasian regimes were different from others, but fundamentally similar to each other. Castles' (1985: 10-109) 'anatomy of an anomaly' attributed the distinctive regime type developed in these countries mainly to the early acquisition of political strength by the working classes and the precocious introduction of universal suffrage. This combination of factors produced innovation mainly within the employment relations system, rather than within the more conventional area of state welfare, compulsory arbitration machinery being the main avenue used for the delivery of minimum standards of living, at least for males. By contrast, as authors like Katzenstein (1985) make clear (also: Castles 1988), the smaller Western European countries, which similarly faced the economic vulnerability inherent to small economies, developed more universalistic welfare state strategies and active labour market policies as the primary components of social protection. Though stress was also placed on minimum standards within employment relations in these countries, social 
protection developed somewhat later than in Australasia. This was largely the product of the trade union movement gaining strength later.

With the noteworthy exception of Sandlant (1989), who is discussed further later, the literature directly comparing employment relations in Australia and New Zealand accepts, largely uncritically, the argument that the two countries had the same basic institutional configuration within the labour market (Ahlquist 2011; Barry and Wailes 2004; Bray and Haworth 1993; Bray and Nielson 1996; Bray and Walsh 1993, 1995; Brosnan et al. 1992; Mitchell and Wilson 1993; Plowman and Street 1993; Wailes 1999; Wailes et al. 2003). Brosnan, Burgess and Rea (1992), for example, treat the course of Australian and New Zealand employment relations during the 1980s and 1990s as two national forms of departure from a single, traditional 'Australasian model'. Similarly, Bray and Walsh (1995: 1) argue that Australia and New Zealand had 'a common industrial relations tradition', having each 'introduced systems of state conciliation and arbitration to govern relations among workers and employers'.

In one sense, the general assumption that Australia and New Zealand were exceptional and highly similar is justifiable, since the literature in question seeks to use the broad historical similarities to lead into its major focus, which is the divergences between Australia and New Zealand since the 1980s. Broadening the subject matter to social protection, it is indisputable that Australia and New Zealand followed similar paths in the period in question. When examined within a broad international comparative perspective, the two regimes do appear to stand out as belonging to their own regime type. Social protection in both countries, as the work of Castles has made clear, revolved around the same major planks: employment relations systems underpinned by minimum standards shaped by the principle of the national minimum; industry protection designed to entice employers to pay decent (male) wages and offer decent conditions; selective immigration policies designed to exclude wage competition from foreign, essentially non-'white' workers; and social security programmes which were used as a last resort or safety net for those aged individuals considered deserving of state-funded income support. It is no accident that Australia and New Zealand together shared the international limelight during the latter part of the nineteenth century and the 
early part of the twentieth. Scholars from Europe, the United Kingdom and the United States applauded 'antipodean' social protection developments (e.g. Twain 1897; Webb, B. 1898a, b; Adams 1892; Métin 1899).

However, understanding the similarities, and more importantly the differences, between national policy regimes requires a deeper interrogation of the substance and the sources of past policies and institutions, and their political context.

\section{Political Interests: Labourism Versus Liberalism}

The political interests which bore upon the formation of social protection in Australia were different from those which influenced the New Zealand pattern. Though, as discussed earlier in this chapter, the two countries developed highly similar overall policy regimes, the factors driving the formation of these regimes were not the same. Australia-New Zealand comparativists, such as Castles (1985) and Bray and Nielson (1996), argue that the working class of each nation was instrumental to the foundation of the employment relations portion of social protection. However, in Australia the early formation of the Labor Party and its early gaining of political office-albeit brief-allowed the wishes of the labour movement to be channelled through parliament more effectively. In New Zealand, on the other hand, the period during which social protection took shape was overseen exclusively by a Liberal government, which ruled from 1891 to 1912, and the Labour Party was not formed until 1916. The Liberals formed New Zealand's first party government.

The Australian Labor Party was first formed in the colony of Queensland in 1890, when a Labor Federation formulated a platform for a representative party. Labor members were elected to parliament in 1891 in the colonies of New South Wales, South Australia and Queensland. Labor entered the Victorian parliament in 1892, and the States of Tasmania in 1900 and Western Australia in 1901. The Australian (federal) Labor Party was formed upon the federation of states in 1901. The Party's federal structure was thereby inaugurated. Despite this, as writers such as Crisp (1978) and Jaensch (1989: 18-20) make clear, the intercolonial ethos within the individual colonial Labor Parties was strong. The Australian 
Labor Federation and intercolonial labour congresses and trade unions provided forums for the fostering of this ethos. In his extensive study of the formation of arbitration and the determination of minimum wage standards in the 1890s and 1900s, Macarthy (1967a; see also Macarthy $1967 \mathrm{~b} ; 1969$; 1970) argues that the relatively high degree of unity between the state and federal Labor Parties after 1901 resulted in the union movement's interests being represented nationally in social protection. After the failure of direct action in the form of the great strikes in the early 1890s:

The broad strategy of labour's [that is, unions'] policy was to act on government as an alternative source of strength. State authority was increasingly conceived as a reservoir of power which could, by astute manipulation, be harnessed to provide a countervailing force to employers' industrial hegemony. In effect labour worked to extend intervention in economic and social affairs to support wage earners' direct and immediate interests.

... [W] hereas formerly particular legislative or administrative measures favouring labour were contrived by electoral bribery, and the representation of parliamentarians sympathetic to wage earners, during our period [1890 to 1910] labour [Labor] parties operated as internal pressure groups on governments.

... A reading of labour council records clearly reveals that throughout these years union policy rested firmly on the pressure that labour parties could bring on governments. All major aspects of policy were referred to members to be translated to administrative or legislative action. Mostly, relations between industrial and political labour were close and harmonious.

... A coincidence of views and alignment of policies was ensured by labour activists operating in both the industrial and political wings of the movement, i.e. in the labour councils and labour electoral leagues. Moreover, many of the most active labour politicians spent years as union leaders, often retaining representative position in or regularly attending meetings of labour councils concurrently with being elected members of legislatures. (Macarthy 1967a: 74)

Australia was in this sense 'labourist' in character, though to a considerable extent the Labor Parties had to rely on sympathy from the ruling non-Labor governments: Protectionist, Liberal and Fusion. Though New Zealand shared much of the Australian pattern of socially protective 
measures during the period in question, the New Zealand union movement's use of parliamentary processes was less apparent, and essentially not labourist.

Labor in Australia did hold office during the twenty years in question, albeit briefly, in Queensland in 1899 (the world's First Labour Government), at the federal level in 1904 and 1908, and again more substantially from 1910 to 1913 . That Australia had a political party which grew from the trade union movement, and influenced policy significantly_-while New Zealand did not-is significant. And as argued in the remaining chapters of the book, this significance runs throughout the history of social protection to this day. In New Zealand the ruling Liberal Party was the first party to come to office. The nation had not yet experienced party governments because it did not have political parties before 1891 (Hamer 1988: 9). The Liberals were less obviously aligned politically than the Australian Labor Party, and at least outwardly resented the very idea of representing the interests of any one class of the people over those of any other class (Davidson 1989: 35-49). Hamer (1988: 40-41) argues that social protection in its formative years was built by a relative political neutrality in government:

Liberals were opposed to the placing of any section [of the population] in a special or privileged position. ... Of course, this principle worked the other way as well. Liberals did not like to see any 'class' placed in an inferior or disadvantaged position. They accepted pro-labour legislation [factory laws and compulsory arbitration] in the early-1890s on the understanding that it was needed to equalize labour and capital, and not to raise labour above capital. One can also see this principle operating in the preferences shown by many Liberals for financing old age pensions out of consolidated revenue rather than specifically from the land tax, as some radicals proposed.

As part of the greater diffusion of interests represented in social protection in New Zealand, it was also more important there for policy to be sensitive to, or reflect, the interests of farmers. In her analysis of New Zealand social protection, Mabbett (1995: 34) argues that, on the occasions which called for the state to defend the arbitration system against union attacks, 'the government acted primarily in response to farming 
interests rather than employer interests'. In addition, writing in the 1990s, Bremer (1993: 108) argues:

For over a century, the agricultural sector has been of crucial importance to the New Zealand economy. Apart from a few brief years during the goldrushes of the 1860s, farmers contributed the greatest part of New Zealand's export earnings. Industrialization has never occurred on a large scale and, while manufacturing and the service sector have grown in importance, they have only recently challenged agriculture as the major earner of overseas exchange. It comes as no surprise, therefore, to find that at least until the 1980 s, State economic policies exhibited a clear bias in favour of the farming community.

\section{Higgins Versus Pember Reeves, Arbitration and the Labour Movement}

The different interests to which social protection responded was also reflected in the affiliations of the major architects of the employment relations system. Higgins, the originator of the Australian basic wage, influenced employment relations in his country so profoundly that 'had he followed in the principles and practice of Justice O'Connor', the first President of the Arbitration Court, who directly preceded Higgins, 'the course of Australian industrial relations may have taken a different direction' (Macarthy 1969: 22). William Pember Reeves similarly shaped New Zealand's labour market institutions, and indeed its reputation as a social laboratory in the 1890s and 1900s. Reeves

had helped to make his country 'a laboratory in which political and social experiments are every day being made for the information and instruction of the older countries of the world'. [quote from Asquith]

Reeves's part in that transformation exceeded that of any other individual. ... With all the caution owed to the idea that important events usually have important causes, deep-rooted in human society, it may be said that it is improbable that compulsory arbitration would have been introduced but for Reeves's personal effort. (Sinclair 1965: 212) 
Higgins was not strictly a member of the labour movement, but he was briefly a minister in the Labor government of 1904 . Reeves, on the other hand, was a minister of the Liberal Cabinet, and was not in any sense a member of the labour movement (Holt 1976; Sinclair 1965). Though both figures were pragmatists, preferring immediate and practically informed action rather than theoretically inspired policy programmes, Higgins seems to have been driven most strongly by concern for the lowpaid, unskilled worker, and the poor. Both figures were influenced significantly by the Fabian socialism of Beatrice and Sidney Webb (Sinclair 1965: 101, 210, 249-252; Palmer 1931: 130), who saw the state, in combination with trade unionism, as the most appropriate conduits through which protections for workers should be channelled. Yet, while Reeves was also deeply concerned to see equality and social justice, his major objective in designing the New Zealand system was to stop strikes and lockouts (Walsh and Fougere 1987: 189; Holt 1976, 1986), and to even up the balance of power between the working and capitalist classes.

Though political parties representing the trade unions in New Zealand were formed at around the same time as in Australia, they were relatively poorly organised and significantly less powerful, essentially constituting makeshift working-class interest representation until the permanent Labour Party was formed in 1916 (discussed at length in Chap. 3). In part this reflects, and is reflected by, the slower pace of industrialisation in New Zealand as compared with Australia. As Olssen and Richardson (1986: 1), argue, for instance, this was manifested in the 'more leisurely' pace with which unionism grew in nineteenth-century New Zealand. Indeed, one prominent New Zealand labour historian argues that 'New Zealand's trade unions were pathetically weak in the 1890s. Only a few small unions had existed prior to 1889' (Holt 1976: 106). Of course, as will be outlined in Chap. 3, unionism subsequently grew significantly more quickly.

That New Zealand saw the phenomenon of new unionism develop slower than Australia was reflected in the considerably lower concentration of its population in large towns. By the late 1880s, 25 percent of New Zealand's population resided within its major urban centres, whereas in Australia the same statistic was 45 percent (Olssen and Richardson 1986: 2). Though urbanisation took hold early in Australia—the legacy 
of which can still be seen today - the rush to live in towns in New Zealand was mitigated significantly by perceptions on the part of farmers and the New Zealand Liberals that urban life was morally inferior to rural life. Large towns were associated with the 'old-world' countries, typically Britain and the United States, which had major problems with poverty, crime, vice and immorality, all seen as stemming mainly from city living (Hamer 1988, especially: 58-60; Bremer 1993: 108). Apart from this factor, the farmers' sense of superior social importance was underpinned by their economic contribution to the nation, in particular to its exports.

\section{Constitutions and Other Institutions}

In expounding the relevant differences between Australia and New Zealand which emerged in the 1890s and 1900s, politics only tells part of the story. Consistent with historical-institutionalist reasoning, it is equally important to consider the broader institutional framework within which social protection was built, and how that framework interacted with political forces at play. An examination of institutions and politics combined not only provides a comprehensive picture of the similarities and differences between the Australian and New Zealand regimes which are of concern here, it also furnishes a framework for analysing the evolution of the regimes subsequently. Institutional architecture in the one period circumscribes policy possibilities in subsequent periods. Therefore the significance of the factors identified here is, in large measure, only realisable upon the analysis of this subsequent history. This speaks to the importance of comparative history informed by the analysis of incrementalist change over long periods of time (Mahoney and Thelen 2010), what this book refers to as the long haul.

A vitally important factor shaping social protection in Australia was the embeddedness of the arbitration system within the federal Constitution. The significance of the different constitutional frameworks in Australia and New Zealand is revealed at various points in the history of the two regimes. However, those differences took root with federation in Australia in 1901, which effectively circumscribed the employment relations role of the federal government from then on. The Constitution 
ascribed a highly limited function for the federal government in the regulation of working conditions. Under Section 51 (xxxv),

[t]he [federal] Parliament shall, subject to this Constitution, have the power to make laws for the peace, order and good government of the Commonwealth [of Australia] with respect to ... Conciliation and Arbitration for the prevention and settlement of industrial disputes extending beyond the limits of any one State. (See further McCallum et al. 1990: 167-357)

Writing in the 1990s, Dabscheck (1993: 6) further notes that ' $t$ the Australia (Commonwealth) government is [was] undoubtedly the only national government in the world which does not enjoy a direct industrial relations power with respect to the private sector'. To be sure, this limitation has been increasingly subject to other constitutional powers, such as those relating to 'corporations' and 'external affairs' laws, which may be (and, especially since the 1980s, have been) tapped as 'back-door' methods of regulation. However, it is important to note here that the Australian Constitution only effectively allowed the government to establish, but not directly to govern, the arbitration system. The Commonwealth Conciliation and Arbitration Act of 1904 established the arbitration system, which in turn set awards which bound employers to provide certain minimum conditions in awards. The government could put its position on wages and other working conditions before the Arbitration Court, but it could not directly set conditions. To the extent that it got its way, it did so through the Court's rulings, though as will be seen in subsequent chapters, governments did not always approve of arbitration tribunals' decisions. As seen earlier, the colonial (later state) governments had their own, similar industrial tribunals, and they tended to follow the federal Arbitration Court (after federation) on matters they perceived to be of national importance.

In contrast to the relative straightjacketing of the Australian government with respect to employment relations, the New Zealand government had relative free rein. Indeed, New Zealand had no written Constitution, though it did and does have various sources of constitutional law (Joseph 1993: 1-112; Harris 1992; Palmer 1992). It was 
government legislation alone, however, rather than legislation circumscribed by a written Constitution, which established the New Zealand arbitration system. Given that the New Zealand Arbitration Court's function was not a constitutionally entrenched feature of the law, the arbitration system was always more susceptible to successful challenge, primarily because the employment relations actors knew that there was some likelihood that the Court could be abolished relatively easily when economic and/or political conditions were ripe for its abolition.

This attests to the importance of institutions to comparative-historical analysis. As the historical institutionalist Steinmo (1989: 535) reminded us in his analysis of tax policy in the United States, Sweden and Britain, 'institutions provide the context in which political actors make their political choices and define their policy preferences'. The first of the major challenges to arbitration in New Zealand was to occur in the period between 1908 and 1913, which will be discussed in the following chapter.

\section{Legislation, and the Family Basis of Wages}

As a sign of the less formidable restraints placed upon New Zealand governments in directly influencing the setting of working conditions, the factory laws which were introduced in that country from the latter part of the nineteenth century could not have occurred (and did not occur) in Australia. Before the federation of the Australian colonies in 1901, an intercolonial labour-legislative framework was prohibited. After Federation, it was still prohibited, mainly because of the limitations placed upon the new federal government, as discussed earlier. While the states could and did legislate certain minimum standards as part of the factory code, the federal government could not. This inability of the government to legislate for nationally applicable minimum labour standards, in combination with the embedding of arbitration within the Constitution, further entrenched the reliance on arbitration as a social protection mechanism in Australia. In the absence of the socially protective function of arbitration, the only major possibility was to change the Constitution so as empower the government to impose national legislation, that is, through a successful referendum. This latter option was a 
somewhat unreliable path to take. Brugger and Jaensch (1985: 172-173) unpacked the difficulty from its source:

Clearly the founding fathers of the Australian Constitution did not believe that their machine would operate without modification for all time. They did, however, lay down formidable barriers to change. ... The proposal for [legislative] change should ideally pass both houses of parliament by an absolute majority; but if it is rejected by one house or if one house fails to pass it within three months, the Governor General may submit the proposal to the electors. The Governor General would presumably only so act on the advice of the government. When submitted to a referendum, the proposal must be supported by a majority of the Australian electorate and be supported by a majority of the electorate in four of the six States. Such were formidable obstacles in 1901.

Apart from the constitutional context, another key aspect of the operation of the arbitration system related to the more explicit family basis of wages after 1907, when H.B. Higgins handed down the Harvester Judgement. Though, as seen earlier in the chapter, the New Zealand Arbitration Court used family needs as a consideration when formulating wages policy, the Court did not set down in a rigid fashion the family needs component of wages. This changed in the 1930s, when a family wage was set by the New Zealand Court. During the early operation of the system, however, a key difference between the Australian and New Zealand social protection regimes was that family policy in Australia was conducted exclusively through the wages system. More generally, the course of social security policy was influenced by the same factor, though again, the situation subsequently changed, and is to be discussed in future chapters.

\section{Conclusion}

In the 1890 s and 1900 s, the similarities in the substance of social protection in Australia and New Zealand were considerable. However, as was demonstrated here, the differences between them have been 
underemphasised in existing comparative accounts. While social protection in Australia resulted from the pursuit of a largely labourist political strategy, the New Zealand story was different. Policy in New Zealand generally reflected more diffuse political forces, and the entire early period was overseen by a Liberal government, New Zealand's first party government.

Institutional factors-particularly those relating to the constitutional frameworks of the two countries - also separated the two countries. The Australian Constitution effectively disallowed direct federal government regulation of employment relations. That function was given to the Arbitration Court. National minimum labour standards legislation, as existed in New Zealand, was therefore precluded, and the awards set down by arbitration provided the only labour market safety net. In New Zealand, the existence of national legislation for an additional safety net rendered arbitration more vulnerable to challenge from trade unions, employers, farmers and/or government, depending on the economic and political conditions at play. Legislation could always replace arbitration. Finally, when this factor is combined with the more explicit relation of wages to family needs in Australia, it becomes clear that family policy was more likely to be pursued as a fruit of arbitration and not of the social security system. In addition, the Australian government faced restraints on the development of social security by the Constitution, which was drawn up with the states in charge of the state welfare system.

Though this factor had not yet proved important in the period examined in this chapter, it was certainly to become fundamental from the 1920 s to the 1940 s, as discussed in the next chapter.

\section{References}

Adams, F. (1892). The Australians: A Social Sketch. Paternoster Square: T. Fisher Unwin.

Ahlquist, J. S. (2011). Navigating Institutional Change: The Accord, Rogernomics, and the Politics of Adjustment in Australia and New Zealand.

Comparative Political Studies, 44(2), 127-154. 
Allan, C., Brosnan, P., \& Walsh, P. (1998). Non-Standard Working Time Arrangements in Australia and New Zealand. International Journal of Manpower, 19(4), 234-249.

Barry, M., \& Wailes, N. (2004). Contrasting Systems? 100 Years of Arbitration in Australia and New Zealand. Journal of Industrial Relations, 46(4), 430-447. Bray, M., \& Haworth, N. (1993). Comparing Australia and New Zealand. In M. Bray \& N. Haworth (Eds.), Economic Restructuring and Industrial Relations in Australia and New Zealand: A Comparative Analysis (Australian Centre for Industrial Relations Research and Teaching Monograph No. 8, ACIRRT) (pp. 1-15). Sydney: University of Sydney.

Bray, M., \& Nielson, D. (1996). Industrial Relations Reform and the Relative Autonomy of the State. In F. G. Castles, R. Gerritsen, \& J. Vowles (Eds.), The Great Experiment: Labour Parties and Public Policy Transformation in Australia and New Zealand (pp. 68-87). Sydney: Allen and Unwin.

Bray, M., \& Walsh, P. (1993). Unions and Economic Restructuring in Australia and New Zealand. In M. Bray \& N. Haworth (Eds.), Economic Restructuring and Industrial Relations in Australia and New Zealand: A Comparative Analysis (Australian Centre for Industrial Relations Research and Teaching Monograph, no. 8, ACIRRT) (pp. 122-155). Sydney: University of Sydney. Bray, M., \& Walsh, P. (1995). Accord and Discord: The Differing Fates of Corporatism Under Labo(u)r Governments in Australia and New Zealand. Labour and Industry: A Journal of the Social and Economic Relations of Work, 6(3), 1-26.

Bremer, R. (1993). Federated Farmers and the State. In B. Roper \& C. Rudd (Eds.), State and Economy in New Zealand (pp. 108-127). Oxford: Oxford University Press.

Brosnan, P., \& Rea, D. (1991). An Adequate Minimum Code: A Basis for Freedom, Justice and Efficiency in the Labour Market. New Zealand Journal of Industrial Relations, 16(2), 143-158.

Brosnan, P., Burgess, J., \& Rea, D. (1992). Two Ways to Skin a Cat: Government Policy and Labour Market Reform in Australia and New Zealand. International Contributions to Labour Studies, 2, 17-44.

Brugger, B., \& Jaensch, D. (1985). Australian Politics: Theory and Practice. Sydney: Allen and Unwin.

Butlin, N. G. (1964). Investment in Australian Economic Development, 1861-1900. Cambridge: Cambridge University Press.

Carney, S., \& Hanks, P. (1994). Social Security in Australia. Oxford: Oxford University Press. 
Castles, F. G. (1985). The Working Class and Welfare: Reflections on the Political Development of the Welfare State in Australia and New Zealand, 1890-1980. Wellington/Sydney: Allen and Unwin.

Castles, F. G. (1988). Australian Public Policy and Economic Vulnerability: A Comparative and Historical Perspective. Sydney: Allen and Unwin.

Castles, F. G. (1996). Needs-based Strategies of Social Protection in Australia and New Zealand. In G. Esping-Andersen (Ed.), Welfare States in Transition: National Adaptations in Global Economies (pp. 88-115). London: SAGE Publications.

Castles, F. G., \& Pierson, C. (1996). A New Convergence? Recent Policy Developments in the United Kingdom, Australia and New Zealand. Policy and Politics, 24(3), 233-246.

Castles, F. G., \& Shirley, I. F. (1996). Labour and Social Policy: Gravediggers or Refurbishers of the Welfare State? In F. G. Castles, R. Gerritsen, \& J. Vowles (Eds.), The Great Experiment: Labour Parties and Public Policy Transformation in Australia and New Zealand (pp. 88-100). Sydney: Allen and Unwin.

Caves, R. E., \& Krause, L. B. (1984). The Australian Economy: A View from the North. Washington: Brookings.

Coghlan, T. A. (1918/1969). Labour and Industry in Australia, Volume $I V$. London: Allen and Unwin.

Crisp, L. F. (1978). The Australian Federal Labour Party, 1901-1951. Sydney: Hale and Iremonger.

Dabscheck, B. (1993). A New Province for Law and Order: The Australian Experiment with Industrial Tribunals. Paper Delivered at the Ninth World Congress of the International Industrial Relations Association, Sydney, August-September.

Davidson, A. (1989). Two Models of Welfare: The Origins and Development of the Welfare State in Sweden and New Zealand, 1888-1988. Uppsala: Acta Universitatis Upsaliensis.

de Garis, B. K. (1974). 1890-1900. In F. K. Crowley (Ed.), A New History of Australia (pp. 216-259). Melbourne: William Heinemann.

Deakin, S., \& Green, F. (2009). One Hundred Years of British Minimum Labour Wage Legislation. British Journal of Industrial Relations, 47(2), 205-213.

Deeks, J., Roth, H., Farmer, J., \& Scott, G. (1978). Industrial Relations in New Zealand. Wellington: Methuen New Zealand.

Deeks, J., Parker, J., \& Ryan, R. (1994). Labour and Employment Relations in New Zealand. Auckland: Longman Paul. 
Deeming, C. (2013). The Working Class and Welfare: Francis G. Castles on the Political Development of the Welfare State in Australia and New Zealand Thirty Years on. Social Policy and Administration, 47(6), 668-691.

Dickey, B. (1987). No Charity There: A Short History of Social Welfare in Australia. Sydney: Allen and Unwin.

Docherty, J. C. (1973). The Rise of Railway Unionism: A Study of New South Wales and Victoria c. 1880-1905. Unpublished MA Thesis, Australian National University.

Ebbels, R. N. (1965). The Australian Labour Movement, 1850-1907. Melbourne: Cheshire-Lansdowne.

Fitzpatrick, B. (1949). The British Empire in Australia: An Economic History, 1834-1939. Melbourne: Melbourne University Press.

Gardner, W. J. (1981). A Colonial Economy. In W. H. Oliver \& B. R. Williams (Eds.), The Oxford History of New Zealand (pp. 57-86). Oxford: Clarendon Press.

Gollan, R. (1960). Radical and Working Class Politics: A Study of Eastern Australia, 1850-1910. Melbourne: Melbourne University Press.

Hamer, D. (1988). The New Zealand Liberals: The Years of Power, 1891-1912. Auckland: Auckland University Press.

Harris, J. (1992). Political Thought and the Welfare State, 1870-1940: An Intellectual Framework for British Social Policy. Past and Present, $135,116-141$.

Hawke, G. (1985). The Making of New Zealand: An Economic History. Cambridge: Cambridge University Press.

Higgins, H. B. (1920). A New Province for Law and Order III. Harvard Law Review, XXXIV(2), 105-136.

Holt, J. (1976, October 10) The Political Origins of Compulsory Arbitration in New Zealand: A Comparison with Great Britain. New Zealand Journal of History, 99-111.

Holt, J. (1986). Compulsory Arbitration: The First Forty Years. Auckland: Auckland University Press.

Jaensch, D. (1989). The Hawke-Keating Hijack: The ALP in Transition. Sydney: Allen and Unwin.

Joseph, P. A. (1993). Constitutional and Administrative Law in New Zealand. Sydney: The Law Book Company Ltd..

Kahn-Freund, O. (1972). Labour and the Law. London: Steven for the Hamlyn Trust. 
Katzenstein, P. J. (1985). Small States in World Markets: Industrial Policy in Europe. Ithaca: Cornell University Press.

Kennedy, R. (1985). Charity Warfare: The Charity Organisation Society in Colonial Melbourne. Melbourne: Hyland House.

Kewley, T. H. (1973). Social Security in Australia, 1900-72. Sydney: Sydney University Press.

Le Rossignol, J. E., \& Stewart, W. D. (1910). State Socialism in New Zealand. New York: Thomas Y Crowell and Co..

Lee, J., \& Fahey, C. (1986). A Boom for Whom? Some Developments in the Australian Labour Market, 1870-1891. Labour History, 50(May), 1-27.

Mabbett, D. (1995). Trade, Employment and Welfare: A Comparative Study of Trade and Labour Market Policies in Sweden and New Zealand, 1880-1980. Oxford: Clarendon Press.

Macarthy, P. G. (1967a). Labor and the Living Wage. Australian Journal of Politics and History, XIII(1), 67-89.

Macarthy, P. G. (1967b). The Harvester Judgement - An Historical Assessment. Unpublished PhD Thesis, Australian National University.

Macarthy, P. G. (1969). Justice Higgins and the Harvester Judgement. Australian Economic History Review, IX(1), 17-38.

Macarthy, P. (1970). Employers, the Tariff, and Legal Wage Determination in Australia - 1890-1910. Journal of Industrial Relations, 12(2), 182-193.

Macintyre, S. (1985). Winners and Losers: The Pursuit of Social Justice in Australian History. Sydney: Allen and Unwin.

Macintyre, S., \& Mitchell, R. (1989). Introduction. In S. Macintyre \& R. Mitchell (Eds.), Foundations of Arbitration: The Origins and Effects of State Compulsory Arbitration, 1890-1914 (pp. 1-21). Melbourne: Oxford University Press.

Mahoney, J., \& Thelen, K. (2010). A Theory of Gradual Institutional Change. In J. Mahoney \& K. Thelen (Eds.), Explaining Institutional Change: Ambiguity, Agency and Power (pp. 1-37). Cambridge: Cambridge University Press.

Markey, R. (1982). The ALP and the Emergence of a National Social Policy, 1880-1910. In R. Kennedy (Ed.), Australian Welfare History: Critical Essays (pp. 103-137). Melbourne: Macmillan.

Markey, R. (1988). The Making of the Labor Party in New South Wales, 1880-1900. Sydney: University of New South Wales Press.

McCallum, R. C., Pittard, M. J., \& Smith, G. F. (1990). Australian Labour Law: Cases and Materials. Sydney: Butterworths. 
Mendelsohn, R. (1979). The Condition of the People: Social Welfare in Australia, 1900-1975. Sydney: Allen and Unwin.

Merritt, A. (1980). The Development and Application of Masters and Servants Legislation in New South Wales - 1845 to 1930. Unpublished PhD Thesis, Australian National University.

Merritt, A. (1982). The Historical Role of Law in the Regulation of EmploymentAbstentionist or Interventionist? Australian Journal of Law and Society, 1(1), 56-86.

Métin, A. (1899). Socialism Without Doctrine, First English translation by Russell Ward (1977). Sydney: Alternative Publishing.

Mitchell, R. (1989). State Systems of Conciliation and Arbitration: The Legal Origins of the Australasian Model. In S. Macintyre \& R. Mitchell (Eds.), Foundations of Arbitration: The Origins and Effects of State Compulsory Arbitration, 1890-1914 (pp. 74-103). Melbourne: Oxford University Press.

Mitchell, R., \& Wilson, M. (1993). Legislative Change in Industrial Relations: Australia and New Zealand in the 1980's. In M. Bray \& N. Haworth (Eds.), Economic Restructuring and Industrial Relations in Australia and New Zealand: A Comparative Analysis (Australian Centre for Industrial Relations Research and Teaching Monograph, No. 8, ACIRRT) (pp. 38-59). Sydney: University of Sydney.

Oliver, W. H. (1977). The Origins and Growth of the Welfare State. In A. D. Trlin (Ed.), Social Welfare and New Zealand Society (pp. 1-28). Wellington: Methuen New Zealand.

Olssen, E., \& Richardson, L. (1986). The New Zealand Labour Movement, 1880-1920. In E. Fry (Ed.), Common Cause: Essays in Australian and New Zealand Labour History (pp. 1-15). Wellington: Allen and Unwin.

Overbye, E. (1997). Mainstream Pattern, Deviant Cases: The New Zealand and Danish Pension Systems in an International Context. Journal of European Social Policy, 7(2), 101-117.

Palmer, N. (1931). Henry Bournes Higgins: A Memoir. Sydney: George G. Harrap and Co..

Palmer, G. (1992). New Zealand's Constitution in Crisis: Reforming our Political System. Dunedin: John McIndoe.

Patmore, G. (1991). Australian Labour History. Sydney: Longman Cheshire.

Plowman, D. (1989). Forced March: The Employers and Arbitration. In S. Macintyre \& R. Mitchell (Eds.), Foundations of Arbitration: The Origins and Effects of State Compulsory Arbitration, 1890-1914 (pp. 135-155). Melbourne: Oxford University Press. 
Plowman, D., \& Street, M. (1993). Industrial Relations and Economic Restructuring in Australia and New Zealand: Employers' Agendas. In M. Bray \& N. Haworth (Eds.), Economic Restructuring and Industrial Relations in Australia and New Zealand: A Comparative Analysis (Australian Centre for Industrial Relations Research and Teaching Monograph, No. 8, ACIRRT) (pp. 91-121). Sydney: University of Sydney.

Quinlan, M. (1989). "Pre-arbitral" Labour Legislation in Australia and its Implications for the Introduction of Compulsory Arbitration. In S. Macintyre $\&$ R. Mitchell (Eds.), Foundations of Arbitration: The Origins and Effects of State Compulsory Arbitration, 1890-1914 (pp. 25-49). Melbourne: Oxford University Press.

Richardson, L. (1981). Parties and Political Change. In W. H. Oliver \& B. R. Williams (Eds.), The Oxford History of New Zealand (pp. 197-225). Oxford: Clarendon Press.

Rickard, J. (1976). Class and Politics: New South Wales, Victoria and the Early Commonwealth, 1890-1910. Canberra: Australian National University Press. Roth, H. (1973). Trade Unions in New Zealand: Past and Present. Wellington: Reed Foundation.

Sandlant, R. A. (1989). The Political Economy of Wage Restraint: The Australian Accord and Trade Union Strategy in New Zealand. Unpublished MA Thesis, Department of Political Studies, University of Auckland, Auckland.

Schedvin, C. B. (1987). The Australian Economy on the Hinge of History. The Australian Economic Review, 20(1), 20-30.

Sinclair, K. (1961). A History of New Zealand. Wellington: Oxford University Press.

Sinclair, K. (1965). William Pember Reeves: New Zealand Fabian. Wellington: Oxford University Press.

Steinmo, S. (1989). Political Institutions and Tax Policy in the United States, Sweden, and Britain. World Politics, 41(4), 500-535.

Sutch, W. B. (1966). The Quest for Security in New Zealand, 1840 to 1966. Wellington: Oxford University Press.

Sutch, W. B. (1969). Poverty and Progress in New Zealand: A Reassessment. Wellington: A.H. and A.W. Reed.

Titmuss, R. M. (1956/1976). The Social Division of Welfare: Some Reflections on the Search for Equality. In K. Titmuss (Ed.), Essays on 'The Welfare State' (pp. 34-55). London: Allen and Unwin.

Turner, I. (1976). In Union is Strength: A History of Trade Unionism in Australia, 1788-1974. Melbourne: Nelson. 
Twain, M. (1897). Mark Twain in Australia and New Zealand. Blackburn: Dominion Press.

Wailes, N. (1999). The Importance of Small Differences: The Effects of Research Design on the Comparative Study of Industrial Relations Reform in Australia and New Zealand. International Journal of Human Resource Management, 10(6), 1006-1030.

Wailes, N., Ramia, G., \& Lansbury, R. (2003). Interests, Institutions and Industrial Relations. British Journal of Industrial Relations, 41(4), 617-637.

Walsh, P., \& Fougere, G. (1987). The Unintended Consequences of Arbitration. New Zealand Journal of Industrial Relations, 12(3), 187-197.

Webb, B. (1898a). The Webbs' Australian Diary. (edited by A.G. Austin), Melbourne: Sir Isaac Pitman and Sons.

Webb, B. (1898b). The Webbs in New Zealand, Beatrice Webb's diary with entries by Sidney Webb, D. A. Hamer (ed.). Wellington: Victoria University Press. Webb, B. (1919). Report of the War Cabinet Committee on Women in Industry: Minority Report by Mrs Sidney Webb. London: His Majesty's Stationery Office. Webb, S., \& Webb, B. (1897). Industrial Democracy. London: Longmans, Green and Co..

Webb, S., \& Webb, B. (1911). The Prevention of Destitution. London: Longmans, Green and Co.

Woods, N. S. (1963). Industrial Conciliation and Arbitration in New Zealand. Wellington: R.E. Owen, Government Printer.

Open Access This chapter is licensed under the terms of the Creative Commons Attribution 4.0 International License (http://creativecommons.org/licenses/ by/4.0/), which permits use, sharing, adaptation, distribution and reproduction in any medium or format, as long as you give appropriate credit to the original author(s) and the source, provide a link to the Creative Commons licence and indicate if changes were made.

The images or other third party material in this chapter are included in the chapter's Creative Commons licence, unless indicated otherwise in a credit line to the material. If material is not included in the chapter's Creative Commons licence and your intended use is not permitted by statutory regulation or exceeds the permitted use, you will need to obtain permission directly from the copyright holder.

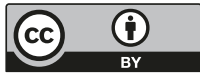

